of the botanical evidence bearing on the climatic and other physical conditions under which coal was formed; and Mr. J. E. Marr continued with a general outline of the geological evidence, laying stress on the peculiar coincidence during the Carboniferous period of a dominant vegetation of giant cryptogams with extensive plains of sedimentation and suitable climatic conditions. The debate thus initiated was then thrown open to the meeting and was carried on briskly by numerous speakers, among whom were Dr. Horace Brown, who gave the result of his experiments on the growth of plants in an atmosphere contain. ing a slight excess of carbonic acid gas, and showed a series of lantern slides illustrating these experiments; Prof. P. F. Kendall, who supported the growth-in-place theory for most coals except cannel-coal; Mr. R. D. Oldham, who referred to the absence of seat-earths or under-clays to the seams in the Indian coal-fields; Dr. D. H. Scott, Dr. H. Woodward, Dr. II. O. Forbes, Dr. Wheelton Hind, Dr. Le Neve Foster, Mr. W. Cash, and others. In winding up this somewhat discursive debate, which had occupied the whole of the morning, the president leant strongly towards the growth-in-place theory, and this view was evidently also in favour with the greater portion of the audience.

Dr. E. D. Wellburn next gave two papers on the fossil fish of the Yorkshire Coal-field and of the Millstone Grits. Mr. J J. H. Teall, President of the Geological Society, then described the plutonic complex of Cnoc-na-Sroine (Sutherlandshire), and discussed the three possible ways in which it may have originated, viz. by (I) successive intrusions ; (2) differentiation in situ ; or (3) modification of the original magma by the absorption of adjacent basic rocks, the conclusion being that the first method has not in this case played an important part, and that the second, coupled perhaps to some extent with the third, has been the main agent in forming the complex. Prof. K. Busz, of Münster, followed with a paper on a granophyre dyke intrusive in gabbro at Ardnamurchan (Scotland), in which it was shown that the granophyre in question has absorbed a considerable quantity of basic material from the previously consoli dated gabbro, and has thereby added hornblende and mica to its proper constituents. Both papers provoked lively discussion.

Tuesday was essentially the glacialists' day and they made vigorous use of it, occupying nearly the whole session. Time was found, however, at the opening for a paper by Miss Igerna B. I. Sollas, "On Naisdites from the Upper Rhætic of Redland, Bristol "; and there was another break at the close, when Prof. A. P. Coleman, of Toronto, gave an account of the recent discovery of a ferriferous horizon in the Huronian north of Lake Superior, where a band of iron-bearing sandstone and jasper has already been traced for sixty miles in the Michipicoton district, and promises to be of great value from both the economic and the scientific standpoints, as it furnishes an easily-recognised horizon, probably equivalent to that containing the most famous iron mines of the United States, and affords an excellent clue to the stratigraphy.

Of the glacial papers, the first, by Mr. F. W. Harmer, was a theoretical discussion of the influence of winds upon climate during past epochs, in which it was sought to restore hypothetically the distribution of cyclonic and anti-cyclonic areas during the Pleistocene period, and to explain in this manner the phenomena of interglacial periods, which the author believes to have occurred alternately in the eastern and western continents, the conditions of comparative warmth and cold during this period having been local and due directly to meteorological causes. Then followed a series of excellent papers on the glacial phenomena of the West Riding, by Dr. Monckman, Mr. E. Wilson, and Messrs. A. Jowett and II. B. Muff, in which particular altention was drawn to the former existence of glacially-dammed lakes in the side valleys draining to the Aire, and to the overflow channels cut by the streams which had their source in these lakes. The glaciation of the East Riding was afterwards dealt with in two papers by Mr. J. W. Stather; and Mr. R. H. Tiddeman brought forward evidence proving that the raised beach of Gower in South Wales, with the bone-beds which rest upon it in the caves, must be either of pre- or inter-Glacial age, since they are overlain by glacial drift; this matter is of much consequence in the correlation of Pleistocene deposits of the unglaciated parts of our island with those of the glaciated tracts.

At the final meeting on Wednesday morning, Mr. R. D. Oldham discussed the mode of formation of the Basal Carboniferous Conglomerate of Ullswater in the light of his Indian experience, and suggested that it was a torrential deposit formed on dry land near the foot of a range of hills, in a generally dry and hot climate varied by seasonal or periodical bursts of rain. In a second paper Mr. Oldham called attention to good examples of new beach-formation on the shores of Thirlmere Reservoir, and recommended that a photographic survey should be made from time to time to record the progress and growth of this beach. Mr. W. H. Crofts followed with a careful and well. illustrated account of sections in Glacial and post-Glacial deposits in a new dock at Hull; and Mr. A. C. Seward gave a summarised description of the Jurassic flora of the Yorkshire coast, with many fine lantern illustrations. Mr. G. W. Lamplugh afterwards reviewed the evidence as to the age of the English Wealden series, and supported the long-accepted but recently questioned view that the whole of the time-interval between the closing stages of the Jurassic and the commence. ment of the Aptian is represented.

The reports of comrnittees of research read during the meeting included, among others, Prof. W. W. Watts', on the collection and preservation of geological photographs; Prof. P. F. Kendall's, on erratic blocks of the British Isles; Dr. Wheelton Hind's, on life-zones in British Carboniferous rocks; and Prof. A. P. Coleman's, on the Pleistocene beds of Canada.

The short afternoon excursions were under the leadership of Mr. J. E. Wilson, Mr. H. B. Muff and Dr. Monckman, who were thus able to show in the field some of the phenomena which they had described in their papers. These excursions were well attended and much appreciated by the visitors from a distance, who in this way were enabled rapidly and pleasantly to gain a grasp of the leading features of the local geology.

A well-arranged temporary museum, under the supervision of Mr. J. E. Wilson, for the exhibition of specimens illustrating the papers and the coal-discussion, was located in a large room adjoining the section room, and was especially serviceable in enabling those interested in the particular subjects illustrated to examine the material at their leisure and to compare notes upon it with the exhibitors. The lantern, so often a source of annoyance at the sectional meetings, was ably managed throughout; and indeed the whole of the local arrangements for the accommodation of the section were admirably planned and carried out, the only drawback being that the noise of heavy traffic on the stone pavement outside was at times troublesome.

To sum up the week's work, it may be remarked that there was an unusual number of papers dealing with subjects of broad general interest and therefore well suited for public discussion, and a scarcity of those detailed studies in stratigraphy or classification which, though probably of more permanent scientific value, are ill-adapted for presentation at these rneetings; the local papers also were numerous and well above the average in character; petrology and palæontology were both adequately represented; but systematic geology received little attention.

The morning meetings were well attended throughout, but, as usual, in the afternoons only the devoted nucleus of the section remained.

\section{ZOOLOGY (AND PHYSIOLOGY) AT THE BRITISH ASSOCIATION.}

THE opening day (Thursday) was devoted to the president's address in the morning and the reports of various com mittees in the afternoon. The reports were as follows :-

(I) Bird migration in Great Britain and Ireland.-Mr. Eagle Clarke has completed the extraction of the voluminous records of occurrences of birds in Great Britain and Ireland from the periodical literature of $1880-1887$. The information thus provided supplements in a most useful manner the original Lighthouse data, and renders it possible for the first time to write an authoritative history of the migrations of each British bird. Mr. Clarke begins the series with a summary of details of the various migratory movements of (i) the Song-Thrush (Turdus musicus) and (ii) the White Wagtail (Motacilla alba).

(2) Investigations at the Naples Zoological Station.-The utility of the British Association's table was again demonstrated by the number of naturalists who had occupied it during the year. Reports on work done there were submitted by Mr. H. M. Kyle (anatomy of flat-fishes), Mr. E. S. Goodrich (structure of certain polychæte worms), Prof. W. A. Herdman (Compound Ascidians), Mr. R. T. Günther (anatomy of Phyllirhö̈ and certain Colenterates), Dr. A. H. R. Buller (fertilisation process 
in Echinoidea) and Prof. Ramsay Wright (methods of preservaion of specimens).

(3) Investigations at the Plymouth Marine Laboratory.- - The British Association table was occupied by Mr. A. D. Darbishire, who investigated the natural history of Pinnotheres and the myology of Calanus; and by Mr. W. M. Aders, who studied the spermatogenesis of Cœlenterates.

(4) Index Animalium.-Mr. C. Davies Sherborne has made great progress in this important work, and the first part of his catalogue of post-Linnæan names up to the year 1800 is now ready for printing.

(5) Plankton of the English Channel.-Mr. Garstang has com pleted the five quarterly surveys provided for, and a final report will be presented at the Glasgow meeting

(6) Zoology of the Sandwich Islands.-Mr. R. C. L. Perkins is again at work in the islands, and reports that already the forests are being extensively destroyed and replaced by sugar cane. It is fortunate for science that the committee foresaw this event, and were enabled to begin their investigations before it was too late. Four parts of the second volume of the "Fauna Hawaiiensis" have been published during the year.

On Friday, Prof. W. B. Scott, of Princeton University, U.S.A., gave an account of the Miocene fauna of Patagonia, based on an elaborate investigation of the Santa Cruz beds. The fauna was characterised by the abundance and variety of Marsupials of Australian type, of Edentates (ground sloths, glyptodons, and armadillos), of porcupine-like Rodents and primilive Ungulates. There was no trace of tree-sloths and anteaters, of rats, mice, squirrels, hares and rabbits, or of carnivoruus Eutheria. The place of the latter was taken by Alesh-eating Marsupials, as in Australia to-day. South America was usually regarded as having no Insectivora, but some of the small mammals examined by him appeared to belong to this class. Among the hoofed animals one series was of particular interest in showing the complete evolution of a one-toed type from three-toed ancestors. This monodactyle positively "out. horsed the hurse," for even the splints had gone. Yet morphologically it was no horse. It furnished the most conclusive instance he knew of convergent evolution in widely separated groups of animals. In conclusion, Dr. Scott showed that, after the removal of the Miocene barrier, the true carnivora of the modern fauna, together with the llama, deer, tapir, peccary, and the haves and rats, immigrated from North America, while the giant sloths and glyptodons extended their range to the northward.

Dr. Gregg Wilson exhibited a number of eggs and embryos of Ornithorhynihus, and described the water-side burrows and nests made by this lowly mammal. The duckmole protects its eggs and nest by blocking the passages between the nest and the entrances with solid walls of earth.

Prof. W. C. McIntosh communicated (through the secretary) a paper on some points in the life-history of the littoral fishes, in which he discussed the mortality of certain shore fishes at different stages of growth.

Major Ronald Ross then delivered a formal lecture on malaria and mosquitoes, dealing more particularly with the life-history of the sporozoan whose reproduction in the blood is the cause of malarial fever, and with the part played by the mosquito Anopheles in transferring the parasite by means of its so-called "salivary" secretion to the blood of fresh human hosts. Native children were the chief source of infection, since their blood swarmed with the parasites. The prevalence of malaria, however, might be reduced by efficient surface-drainage, which would check the multiplication of mosquitoes by destroying the pools and ditches in which their larve were developed.

In the afternoon Prof. S. J. Hickson exhibited microscopic preparations of Dendrocometes, demonstrating the existence of micronuclei in this suctorian, and the remarkable fusion of the macronuclei during conjugation. He advocated the employment of brazilin with iron-alum as a convenient substitute for the iron hæmatoxylin method of staining.

Dr. J. F. Gemmill described the anatomy of the head in cyclopean trout embryos. The cerebral lobes are more or less united, and the trabeculae cranii are fused together anteriorly, and bent down below the median eye or eyes. The infundibulum and pituitary body are entirely absent; the optic nerves are rudimentary or absent, and the eyes, though provided with retina and choroid, have no choroidal fissure. In some specimens the mouth opening is absent, and the lower jaw arch greatly shortened.

No. I6I 5 , vo[. 62$]$
Prof. R. Burckhardt of Basel communicated two papers on some causes of brain-configuration in selachians, and on the systematic value of the brain in selachians. He showed the profound influence of the position of the eyes and other superficial organs upon the shape of the brain, and advocated the employment of cerebral characters in the classification of cartilaginous fishes.

On Saturday, the papers were of a more or less physiological character, as follows :-

Prof. Marcus Hartog: "On a peptic zymase in young embryos," in which the author anuounced the confirmation of his discovery in 1896 of a peptic zymase in young embryos of the frog, in the entire embryo of the chick after twenty-four hours, and in the extra-vascular blastoderm of the three days' chick. He concluded that the law holds good for animals, as well as plants, that the cell cannot directly utilise the reserves it contains, but only the products of their hydrolysis, and this hydrolysis is not a function of the living protoplasm, but of the zymases it forms. These facts also explain apparent exceptions to Herbert Spencer's law of division at the doubling of the volume. A cell that is only accumulating reserve material has no need to constantly readjust its surface to its volume. When, however, the formation of a zymase enables it to utilise its reserves, and its protoplasm grows at the expense of the products of their digestion, the need for augmented surface declares itself, and we get the repeated cell divisions so marked in the "segmentation" of the embryo.

Dr. R. Irvine: "On the mechanical and chemical changes which take place during the incubation of eggs." Hen's eggs during incubation lose weight daily, principally through the oxidation of their carbon and hydrogen, parts of which pass off as $\mathrm{CO}_{2}$ and $\mathrm{H}_{2} \mathrm{O}$ through the shell. The percentage of ash is increased by absorption of line from the shell.

Prof. Gotch described some recent experiments on the physiological effect of local injury in nerve which led to the important conclusion that an electrical disturbance was not always a concomitant of the passage of a nervous impulse.

In addition to the above, Prof. Johnson Symington read papers on the articulations between occipital bone and atlas and axis in the mammalia, and observations on the development of the cetacean flipper, and exhibited a convenient hand-magnifier for demonstrating slide-preparations to lecture-classes (Erbe, Tübingen).

The reports of committees on the following subjects were also communicated:-(I) The physiological effects of peptone when introduced into the circulation (Prof. W. H. Thompson). (2) Comparative histology of the suprarenal capsules (Mr. Swale Vincent). (3) The vascular supply of secreting glands (Dr. J. L. Bunch). (4) Electrical changes in mammalian nerve (Dr. J. S. MacDonald), and (5) The comparative histology of cerebral cortex (Dr. G. Manu).

On Monday, Mr. R.T. Günther read a note on Mnestra parasites, Krohn, in which he submitted reasons for referring this parasitic medusa to the family Cladonemidæ (Anthomedusæ), owing to its possession of compound tentacles with clavate appendages and other cladonemid characters.

Prof. L. C. Miall reviewed the respiratory organs of aquatic insects. He contrasted the slight nature of the adaptations to aquatic life which are exhibited by adult insects with the remarkable modifications for the same end which occur in insect larvæ. He explained the difference as probably due to the fact that profound structural changes in adult insects would interfere with their powers of flight, which were of importance for mating and other purposes. Among larvæ there were two principal lines of modification, (I) specialisation of the spiracular apparatus by which air could be inspired directly from the atmosphere through the surface film of water, and (2) development of a clused tracheal system, by which air was extracted from its solution in the surrounding water. This latter series culminated in a purely vesicular system, destitute of tracher, and finding its nearest parallel in the air-bladder apparatus of physoclist fishes.

Mr. T. H. Taylor described the tracheal gills of Simulizm, whose mode of respiration presented peculiar difficulties still unsolved.

Mr. J. J. Wilkinson described the pharynx of Eristalis, and Mr. N. Walker the structure and life-history of the gooseberry sawfly.

In the afternoon Mr. Stanley Gardiner opened with the interim report of the committee appointed to investigate the 
structure, formation and growth of the coral reefs of the Indian Ocean. Special attention was given to the island of Minikoi, in the Laccadive group. It was clear from their observations that in this atoll there had been an elevation of the original reefs to a height of at least 25 feet above low tide level. All their evidence showed that the lagoons of atolls were generally formed by the solution of the central rock of originally more or less flat reefs.

Prof. R. Burckhardt followed with a paper on the anatomy and systematic position of the Læmargidæ. $\mathrm{He}$ recurded the discovery of luminous organs in nine species of Læmargidæe and Spinacide. The affinity of these families of sharks was further evidenced by his discovery of a cartilage hook in the dorsal fins of Laemargus.

Prof. Burckhardt also showed photographs and other illus. trations of the nestling kagu (Rhinochetus), a rare flightless bird of New Caledonia.

Prof. R. J. Anderson described the dentition of the seal ; and Mr. Graham Kerr, on behalf of Mr. G. E. H. Barrett-Hamilton, exhibited some skulls of Antarctic seais (chiefly Phocidæ) brought home by the Belgian expedition.

On Tuesday, Mr. N. Annandale exhibited a number of photographic slides illustrating the appearance and habits of some Malay insects under natural conditions. One striking series represented the pupa of a Mantis (Hymenopus bicornis) seated on an inflorescence of the so-called "Straits Rhododendron" (Melastoma polyanthum), a detailed resemblance to which is brought about by the colour and shape of the insect, and by the extraordinary attitude which it adopts upon the flower.

Prof. E. B. Poulton also showed a large number of slides, representing the collections of insects made by $\mathrm{Mr}$. G. A. K Marshall in Mashonaland and Mr. R. Shelford in Borneo, as arranged in the Oxford Museum to illustrate the general prin. ciples of Miillerian mimicry. An interesting series of mutilated butterflies caught at large showed the comparative rarity of in discriminate injuries by birds, and the frequency with which enemies aimed at the conspicuously marked tips of the forewings and at the back of the hind-wings, where tail-like processes were so commonly developed, these being just the places where the bites would be least dangerous to the insects.

Other slides, illustrating mimicry and protective resemblance, were exhibited by Mr. Mark L. Sykes ; and Prof. Lloyd Morgan described some recent experiments upon newly-hatched chicks, which showed that the avoidance of distasteful forms by birds is not instinctive, but the fruit of experience. Chicks fed for a time on palatable food placed on black-and-orange banded slips of glass did not hesitate to attack the distasteful caterpillars of the cinnabar moth when these were eventually offered them; whereas chicks which had been accustomed to associate the same coloured slips with bad food refused to attack the similarly striped caterpillars. These observations provided a sound experimental basis for the Müllerian theory of mimicry.

Mr. F. W. Gamble described the results of investigations made by Mr. F. W. Keeble and himself on the colour changes of various prawns, especially Hifpolyte varians, his paper being illustrated by a series of living specimens as well as by lantern slides. The prawns adapted their colours to those of surround ing weeds; but, whatever their colour during the day, they always assumed a characteristic blue colour at night. This change, in newly-caught specimens, came on at the proper time quite independently of the darkness, and the morning phase would be resumed at daybreak, even when the animal was kept in the dark. After a few days under such unnatural conditions, however, the periodicity became altered.

A paper, by Dr. Eneas Munro, on the locust plague and its suppression concluded the business of the section.

\section{GEOGRAPHY AT THE BRITISH ASSOCIATION.}

THE work in Section $\mathrm{E}$ at the Bradford meeting was somewhat limited in amount, but its quality was in no way below the average. In fact, the number of "popular" papers was smaller than usual, while those of a more serious character predominated. The section was excellently housed in the Church Institute, and the meeting began with a presidential address of quite a novel character. Sir George Robertson took the British Empire as his text, and laid great stress on the relative shrinkage of distances by the improvement of means of communication by land and sea, a fact which in great measure neutralised such ill effects as might arise from continuous expansion of territory.

The keynote struck by the president was geography as the science of distances, and in unison with it a series of papers dealt with problems of which distances and means of transport were the essential features. Mr. E. G. Ravenstein discussed the question of foreign and colonial surveys in a comprehensive paper, in which he pointed out the manner and extent of the official surveys of the chief countries of the world. While recognising that the British Ordnance Survey fell short of perfection, he considered that its accuracy was not equalled by the maps of any other country. He strongly urged the adoption of a more systematic method of surveying in Africa, in many parts of which the only existing maps were produced by travellers with in. adequate assistance and many other things to do. In commenting on the paper, Colonel Johnston, the Director-General of the Ordnance Survey, explained the position of South $\Lambda$ frica with regard to its surveys. He said that a nearly perfect system of triangulation had been carried out, but this has not yet been utilised by being made the foundation of a detailed survey.

Mr. B. V. Darbishire read a paper on military maps, with special reference to the use of the Ordnance Survey Maps in field manœuvres.

Colonel Sir Thomas II. Holdich discussed the question of a railway connection between Europe and India. He considered the northern approaches to India across Kashmir or the Hindu Kush from the Oxus valley to be impracticable. On the other hand there appeared to be no insurmountable difficulty in the way of a connection by the Hari-rud valley, through which approach a distance of only 500 miles intervened between the farthest outposts of the existing railways, Kushk on the Russian side and New Chaman on the Indian. The new line would pass by Kandahar. This line could, in the opinion of the author, he made to pay by local traffic, and he believed it would strengthen rather than weaken the defences of India.

Mr. C. Raymond Beazley read a paper, which was largely historical and statistical, on the Trans-Siberian railway.

Mr. G. G. Chisholm gave a very timely forecast of the probable economic changes which may be expected to result from the imminent development of the resources of China by modern methods. These would include, in his opinion:-A rise in prices in China, especially in the industrial regions: a demand for food-stuffs not likely to be supplied by China itself; a great stimulus to the fond-producing regions most favourably situated for meeting this demand, more particularly Manchuria, Siberia, and western North America; and the creation of a tendency to a gradual but prolonged rise in wheat and other grain prices all the world over, reversing the process that has been going on since about 1870 .

Mr. Edward Heawood treated of the commercial resources of tropical Africa, and his paper also partook of the spirit of forecast, his expectations being that Africa will greatly increase in importance by the cultivation of tropical plantations.

The travel papers which excited the most interest ware those contributed by Mr. Borchgrevink on his expedition to the Antarctic regions and by Captain II. H. P. Deasy on his journeys in Central Asia. Both were illustrated by remarkably fine lantern slides. As the facts which they recounted have already been published, it is unnecessary to summarise them here.

Physical geography occupied a large part of the time of the section, and, with regard to this part of the work, it is impossible to refrain from expressing the desire that some arrangement might be come to with regard to the section in which papers lying on the borderland between different subjects should be treated. With regard to meteorology, for instance, might it not be arranged to read all climatological papers-wthe essential principle of which is geographical distribution-at Section $\mathrm{E}$, and only the theoretical papers or those dealing with instruments and atmospheric physics at Section $A$ ?

On this occasion the report of the committee on the climate of tropical Africa, of which Mr. H. N. Dickson is secretary, was read to Section $E$, and a remarkable discussion of the geographical distributions of relative humidity was presented by Mr. E. G. Ravenstein to the same section. In this he said that, notwithstanding the paucity of available material, he had ventured, in 1894, to publish in Philip's "System. atic Atlas," a small chart of the world showing the distribution of humidity, and he now placed the results before this meeting with some diffidence. His charts brought out the broad teatures of the subject, and to reduce the sources of error

NO. 16 I 5, VOL. 62$]$ 